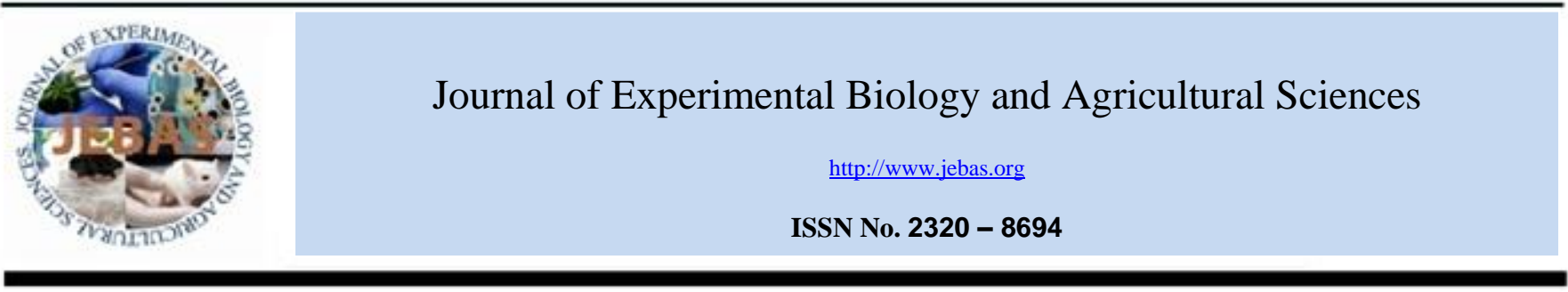

\title{
EFFECT OF DILUTORS, BREED AND PRESERVATION TIME ON EXTRACELLULAR ENZYMATIC ACTIVITY OF PRESERVED BOAR SEMEN
}

\section{Shivanand Kanshi ${ }^{1}$ and Ravindra Kumar, ${ }^{2, *}$}

${ }^{1}$ Veterinary officer, State Animal Husbandry Welfare Board, Ranchi, Jharkhand, India

${ }^{2}$ Scientist-cum-Asstt. professor, Department of LPM, Birsa Agricultural University, Kanke, Ranchi- 834006, Jharkhand, India

Received - September 14, 2016; Revision - September 28, 2016; Accepted - October 04, 2016

Available Online - October 13, 2016

DOI: http://dx.doi.org/10.18006/2016.4(Spl-2-SSPN).S53.S58

\section{KEYWORDS}

Boar semen

Preservation

Diluters

Extracellular enzymes

Pig

* Corresponding author

E-mail: ravindrakumar_rvc@yahoo.com (Ravindra Kumar)

Peer review under responsibility of Journal of Experimental Biology and Agricultural Sciences.

Production and Hosting by Horizon Publisher India [HPI] (http://www.horizonpublisherindia.in/).

All rights reserved

\begin{abstract}
Semen samples were collected from breeds of boars comprising Large White Yorkshire, Tamworth and Cross of Tamworth and Local breed (T \& D) breeds. Experimentation was conducted by collecting 216 semen samples from nine boars. After evaluation of neat semen, samples were diluted with Kiev, Modena and Lactose Egg Yolk dilutors (LEY) subsequently preserved at $15^{\circ} \mathrm{C}$ in BOD incubator for up to 96 hours. Diluted semen samples were evaluated at different hours of interval starting at 24 hours interval up to 96 hours for extra-cellular enzyme activity of Aspartate Amino Transferase (AST) and Alanine Amino Transferase (ALT). In neat semen significant $(\mathrm{P}<0.01)$ effect of breed on extracellular activity of AST and ALT was recorded and it was lower in T\&D boar. Mean extracellular level of AST and ALT did not vary significantly in any of these dilutors and breeds during observed hours of preservation. Irrespective of breeds, extracellular levels of AST and ALT were significantly lower in LEY followed by Kiev and Modena dilutors at 24, 48, 72 and 96 hours of preservation. These dilutors varied significantly at 72 and 96 hours duration of preservation among themselves. Whereas at 24 and 48 hours of preservation, they did not vary significantly between Kiev and LEY dilutors. It was found that irrespective of dilutors, AST and ALT level differed significantly between breeds only at 0 hours of preservation. At other hours of preservation difference in levels of AST and ALT was not found significant between breeds.
\end{abstract}

All the article published by Journal of Experimental Biology and Agricultural Sciences is licensed under a Creative Commons Attribution-NonCommercial 4.0 International License Based on a work at www.jebas.org.

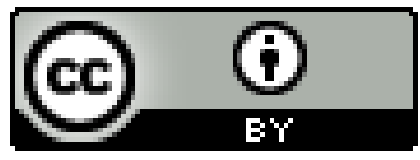




\section{Introduction}

Pig is the highest litter bearing capacity among meat producing livestock species. They have faster growth rate, shorter generation interval, and higher dressing percentage along with high feed conversion efficiency. Hence, pig enterprise is one of the important solutions to bridge the gap between demand and supply of animal protein. Scarcity of superior boars and high cost of rearing them for small and marginal farmers necessitate use of Artificial Insemination (A.I.). This technique is a scientific breeding tool for livestock production and for rapid multiplication of germplasm of superior boars. The practice of artificial insemination on commercial basis exists in some of countries but in India, its application in pig breeding is very limited.

Although sow has considerable influence on conception rate, litter size; recent studies indicated boar has significant influence over it as well as on birth weight, survival of piglets due to genetic factors and variation in semen quality (Skjervold, 1963; Rasbech, 1969). Therefore, evaluation of semen quality at ejaculation as well as at utilization time is essential for improvement in fertility and prolificacy of sow. Microscopic evaluation of spermatozoa does not provide all information necessary to explain potential fertility of male. Study of certain enzymes had shown functional significance in evaluation of male fertility. Highly significant negative correlation between Lactic Dehydrogenase (LDH) activity and non-return conception rate has been observed. Positive correlation between AST activity and fertilizing ability of spermatozoa has been recorded (Pangawkar et al., 1988). Leakage of enzyme from spermatozoa subjected to preservation is accompanied by lowering of their biological value and this phenomenon corresponds to morphological state of sperm structures.

Several extenders are currently in use throughout the world by commercial artificial insemination centers. Among them, Kiev is the most widely used dilutor. In some experiments Belt's Ville Thaw solution (BTS) has given better fertility results than Kiev. Inspite of sufficient literature available on different characters of semen yet no single characteristics has been identified which could serve as trustworthy indicator of its fertility. Therefore, semen sample evaluated on the basis of different parameters must be substantiated by fertility rate.

\section{Materials and Methods}

\subsection{Experimental Animals}

Present study was conducted on semen samples obtained from three Large White Yorkshire, three Tamworth and three T\&D boars (of approximately 2-3 years of age) belonging to Government Pig Breeding Farm, Kanke and Pig Breeding Farm, Ranchi. Veterinary College, Kanke, Ranchi. Boars were maintained under identical ration schedule and management conditions. They were trained for semen collection on oestrus sows.

\subsection{Collection of Semen}

Semen samples were collected twice a week from each boar by gloved hand technique following the procedure of Zavos \& Liptrap (1987). After observing positive response of mounting on restrained estrus female, boar was used for semen collection. The sperm rich portion of the ejaculate was collected in preheated sterilized thermos flask of $500 \mathrm{ml}$ capacity at $40^{\circ} \mathrm{C}$. The opening of flask was covered with clean and sterilized muslin cloth. At the end of collection muslin cloth with gel mass was removed and thermos was capped immediately.

\subsection{Processing of Semen}

A total of 54 semen samples (6 ejaculates obtained each from 3 Large White Yorkshire, 3 Tamworth and 3 T \& D boars) were used by split sample technique for studying effect of different dilutors, preservation time on preservability of spermatozoal characteristics and enzyme activities of semen during preservation at $15^{\circ} \mathrm{C}$. Dilutors used were Kiev (Johnson et al., 1981), Modena (Sone et al., 1992) and Lactose egg yolk (Park $\&$ Pursel, 1985). Original dilutors were slightly modified by replacing antibiotics used in dilutors with Gentamicin sulphate alone in the present study.

Various constituents of dilutors were mixed and kept overnight at $5^{\circ} \mathrm{c}$ in a refrigerator except egg yolk in Lactose egg yolk dilutor. Semen extenders were warmed to $37^{\circ} \mathrm{c}$ and egg yolk was added in case of Lactose egg yolk dilutor before collection of semen. Immediately after collection, thermos flask containing semen was tightly closed and brought to laboratory. After 15-20 minutes from collection time, each ejaculate was split into 3 parts and was diluted at the rate of 1:8 with these three dilutors. The diluted semen was later filled in $(20 \mathrm{ml})$ capacity glass vials having rubber stopper and preserved at $15^{\circ} \mathrm{C}$ in a BOD incubator up to 96 hours. For each dilutor per ejaculate one vial with extended semen was preserved. The preserved semen samples were evaluated at 24, 48, 72 and 96 hours of preservation for enzymatic estimation.

\subsection{Enzyme estimation}

Activities of Aspartate Aminotransferase (AST) and Alanine Aminotransferase (ALT) were estimated in seminal plasma of undiluted, freshly diluted and preserved semen samples. The preserved semen samples were taken out from B.O.D. incubator $\left(15^{\circ} \mathrm{C}\right)$, warmed up to $37^{\circ} \mathrm{C}$ and then centrifuged at $1500 \mathrm{rpm}$ for 20 minutes to obtain seminal plasma. Eighteen samples from each boar were utilized for assay of these enzymes. The enzyme activity was calculated according to procedure followed by Span Diagnostic Private Limited, Surat (India). 
Activity of AST was estimated using diagnostic reagent kit supplied by Span Diagnostics Private Limited, Surat, by the method of Reitman \& Frankel (1957). These were Reagent 1 Buffered Aspartate - $\alpha$ - KG substrate, $\mathrm{pH} 7 \cdot 4$; Reagent 2 DNPH Colour Reagent; Reagent 3 - Sodium hydroxide, 4 N; Reagent 4 -Working Pyruvate Standard $2 \mathrm{mM}$;

Solution I was prepared by diluting $1 \mathrm{ml}$ of Reagent 3 to $10 \mathrm{ml}$ distilled water. Reagent 1,2 and 4 did not require any preparation.

\section{Results}

The mean values of extracellular activity of Aspartate aminotransferase (AST) and Alanine aminotransferase (ALT) in different breeds and dilutors at different hours of preservation were presented in Tables 1, 2, 3 and 4. The results of analysis of variance were presented in Tables 1a and $2 \mathrm{a}$.

\section{1 Effect on Aspartate Amino Transferase}

Breed wise activities of AST in preserved semen samples in different dilutors were depicted under Table 1. Non-significant effect of interactions between breeds and dilutors at studied hours of preservation was noticed. Analysis of variance revealed significant $(\mathrm{P}<0.01)$ variation between breed at 0 hour and dilutors had significant effect at different hours of preservation except at 0 hour. The influence of dilutors irrespective of breed was significant $(\mathrm{P}<0.01)$. The level of AST enzyme was significantly higher (Table 3) in Modena dilutor than Kiev \& LEY dilutors at all the hours of preservation. Critical difference test (Table-3) revealed that AST level irrespective of breed was significantly higher in
Modena than in Kiev and LEY dilutor at all the hours of preservation. All the three dilutors differed significantly among themselves (Table 3) at 72 and 96 hours of preservation. Whereas at 24 and 48 hours of preservation they did not vary significantly between Kiev and LEY dilutors. It further revealed that irrespective of dilutors (Table 4) AST level differed significantly between breeds only at 0 hours of preservation which was significantly highest $182.58 \pm 1.49$ units $/ 10^{9}$ sperms in Large White Yorkshire followed by 176.57 \pm 1.90 units $/ 10^{9}$ sperms in Tamworth \& $174.79 \pm 1.87$ units $/ 10^{9}$ sperms in $\mathrm{T} \& \mathrm{D}$ boars.

\section{2 Effect on Alanine Amino Transferase}

Breed wise enzymatic level of ALT in different dilutors \& breeds has been furnished under Table-2. Significant $(p<0.01)$ effect of dilutors on the level of ALT enzyme in all three breeds at different hours of preservation. The effect of breed on ALT level was also significant $(\mathrm{P}<0.01)$ while the effect of interaction between breed and dilutors were found nonsignificant at varied hours of preservation. The influence of dilutors irrespective of breed was significant $(\mathrm{P}<0.01)$. Critical difference test (Table-3) revealed that ALT level irrespective of breed was significantly higher in Modena than Kiev, Lactose egg yolk dilutors at different hours of preservation. But it did not show any significant difference between Kiev and Lactose egg yolk dilutors. The study further revealed that irrespective of dilutors, ALT level was significantly highest in Large White Yorkshire $45.39 \pm 0.37$ units $/ 10^{9}$ sperms followed by Tamworth $(41.91 \pm 0.69$ units $/ 10^{9}$ sperms) and $\mathrm{T} \& \mathrm{D}$ boars $\left(39.81 \pm 0.67\right.$ units $/ 10^{9}$ sperms) at 0 hours of preservation only (Table-4). At all other hours of preservation difference between levels of ALT was not significant between breeds.

Table 1 Mean extracellular AST activity (units $/ 10^{9}$ Sperms) of boar semen during preservation with different dilutors*.

\begin{tabular}{|c|c|c|c|c|}
\hline \multirow{2}{*}{$\begin{array}{c}\text { PERIOD OF } \\
\text { PRESERVATION }\end{array}$} & \multirow[t]{2}{*}{ BREED } & \multicolumn{3}{|c|}{ DILUTORS } \\
\hline & & KIEV & MODENA & LEY \\
\hline \multirow[t]{3}{*}{0 Hour } & LARGE WHITE YORKSHIRE & $184.61 \pm 1.40$ & $182.67 \pm 3.12$ & $180.45 \pm 2.92$ \\
\hline & TAM WORTH & $177.22 \pm 2.75$ & $177.67 \pm 3.39$ & $174.83 \pm 3.82$ \\
\hline & $\mathrm{T} \& \mathrm{D}$ & $175.28 \pm 2.69$ & $175.94 \pm 3.35$ & $173.17 \pm 3.75$ \\
\hline \multirow[t]{3}{*}{24 Hour } & LARGE WHITE YORKSHIRE & $343.06 \pm 7.74$ & $511.44 \pm 2.53$ & $346.5 \pm 6.08$ \\
\hline & TAM WORTH & $347.89 \pm 7.21$ & $508.78 \pm 2.74$ & $344.5 \pm 6.45$ \\
\hline & $\mathrm{T} \& \mathrm{D}$ & $342.17 \pm 7.5$ & $506.94 \pm 2.07$ & $339.83 \pm 6.09$ \\
\hline \multirow[t]{3}{*}{48 Hour } & LARGE WHITE YORKSHIRE & $627.07 \pm 9.14$ & $683.11 \pm 3.55$ & $626.89 \pm 7.09$ \\
\hline & TAM WORTH & $632.33 \pm 8.31$ & $682.11 \pm 3.10$ & $628.67 \pm 6.11$ \\
\hline & $\mathrm{T} \& \mathrm{D}$ & $630.61 \pm 8.26$ & $679.17 \pm 3.22$ & $626.72 \pm 6.14$ \\
\hline \multirow[t]{3}{*}{72 Hour } & LARGE WHITE YORKSHIRE & $752.45 \pm 7.39$ & $824.5 \pm 4.86$ & $749.61 \pm 6.54$ \\
\hline & TAM WORTH & $762.72 \pm 4.63$ & $822.00 \pm 4.77$ & $746.67 \pm 6.77$ \\
\hline & $\mathrm{T} \& \mathrm{D}$ & $758.67 \pm 5.08$ & $820.28 \pm 4.72$ & $744.22 \pm 6.87$ \\
\hline \multirow[t]{3}{*}{96 Hour } & LARGE WHITE YORKSHIRE & $789.56 \pm 7.41$ & $864.11 \pm 5.45$ & $785.00 \pm 7.59$ \\
\hline & TAM WORTH & $800.56 \pm 5.55$ & $864.67 \pm 4.94$ & $785.17 \pm 7.03$ \\
\hline & $\mathrm{T} \& \mathrm{D}$ & $798.5 \pm 5.69$ & $863.00 \pm 4.89$ & $782.61 \pm 7.08$ \\
\hline
\end{tabular}

*Each value is average of 18 observations 
Table 2 Mean extracellular ALT activity (units $/ 10^{9}$ Sperms) of boar semen during preservation with different dilutors*.

\begin{tabular}{|c|c|c|c|c|}
\hline \multirow{2}{*}{$\begin{array}{c}\text { PERIOD OF } \\
\text { PRESERVATION }\end{array}$} & \multirow[t]{2}{*}{ BREED } & \multicolumn{3}{|c|}{ DILUTORS } \\
\hline & & KIEV & MODENA & LEY \\
\hline \multirow[t]{3}{*}{0 Hour } & LARGE WHITE ORKSHIRE & $43.78 \pm 0.50$ & $44.61 \pm 0.52$ & $47.78 \pm 0.50$ \\
\hline & TAM WORTH & $40.11 \pm 1.24$ & $41.33 \pm 1.08$ & $44.28 \pm 1.16$ \\
\hline & $\mathrm{T} \& \mathrm{D}$ & $37.89 \pm 1.22$ & $39.17 \pm 1.01$ & $42.39 \pm 1.00$ \\
\hline \multirow[t]{3}{*}{ 24Hour } & LARGE WHITE ORKSHIRE & $94.33 \pm 2.33$ & $103.44 \pm 2.84$ & $93.83 \pm 2.18$ \\
\hline & TAM WORTH & $92.28 \pm 2.47$ & $101.89 \pm 2.71$ & $91.61 \pm 2.43$ \\
\hline & $\mathrm{T} \& \mathrm{D}$ & $90.78 \pm 2.43$ & $99.67 \pm 2.86$ & $89.67 \pm 2.46$ \\
\hline \multirow[t]{3}{*}{48 Hour } & LARGE WHITE ORKSHIRE & $144.94 \pm 3.74$ & $159.11 \pm 4.52$ & $149.44 \pm 2.89$ \\
\hline & TAM WORTH & $143.78 \pm 3.64$ & $157.78 \pm 4.49$ & $147.44 \pm 3.05$ \\
\hline & $\mathrm{T} \& \mathrm{D}$ & $142.28 \pm 3.66$ & $155.78 \pm 4.43$ & $145.94 \pm 2.79$ \\
\hline \multirow[t]{3}{*}{72 Hour } & LARGE WHITE ORKSHIRE & $193.00 \pm 3.08$ & $206.61 \pm 4.94$ & $188.33 \pm 5.19$ \\
\hline & TAM WORTH & $191.17 \pm 3.06$ & $221.61 \pm 7.54$ & $186.56 \pm 5.11$ \\
\hline & $\mathrm{T} \& \mathrm{D}$ & $189.5 \pm 3.00$ & $202.83 \pm 4.84$ & $184.5 \pm 5.05$ \\
\hline \multirow[t]{3}{*}{96 Hour } & LARGE WHITE ORKSHIRE & $208.61 \pm 2.36$ & $222.44 \pm 5.09$ & $203.67 \pm 5.37$ \\
\hline & TAM WORTH & $206.28 \pm 2.32$ & $239.72 \pm 7.46$ & $202.11 \pm 5.39$ \\
\hline & $\mathrm{T} \& \mathrm{D}$ & $204.83 \pm 2.30$ & $220.94 \pm 4.80$ & $200.22 \pm 5.30$ \\
\hline
\end{tabular}

*Each value is the average of 18 observations.

\section{Discussions}

4.1 Aspartate Aminotransferase (AST)

This enzyme is located primarily in mid piece of sperm cell (Mann \& Mann, 1981) and measurement of its release is considered to be a sensitive indicator of sperm damage occurring during preservation (Pursel et al., 1970; Brown et al., 1971, Bower et al., 1973, Forejtek \& Navratil 1984). Ciereszko et al. (1992) also reported that GOT/AST release into extracellular medium was best indicator of cell damage. High correlation coefficient between AST activity and fertilizing ability of spermatozoa (Pangawkar et al., 1988) has been recorded. Leakages of enzymes from spermatozoa subjected to preservation were accompanied by lowering of their biological value. Boar semen contains $0.86 \pm 0.04 \mathrm{mg}$ percent of ammonia (Khomyak, 1984) and functional significance of transaminases was attributed to their ability to decrease level of ammonia produced by de-amination of adenyl derivatives. On perusal of Table-3, significantly lowest value of enzyme was recorded in Lactose Egg Yolk followed by Kiev and Modena dilutors. Irrespective of dilutors, extracellular AST level was significantly not different in any breeds of boar. Pandey (1993) reported significant effect of dilutors on extracellular activity of AST in boar semen. Higher and lower value of extracellular enzyme with different dilutors reflected protective properties of ingredients added in dilutor. Increasing trend in AST level with increasing hours of preservation with three dilutors was observed in the present study, which is similar to findings of Azawi et al. (1990) and Pandey \& Singh (2001).

Table 3 Dilutor wise average enzymatic activity at different hours of preservation (Irrespective of breeds)*.

\begin{tabular}{|c|c|c|c|}
\hline Period of preservation & Dilutors & AST Units $/ 10^{9}$ sperms & ALT Units $/ 10^{9}$ sperms \\
\hline \multirow[t]{3}{*}{0 Hour } & KIEV & $179.04 \pm 1.45^{\mathrm{a}}$ & $41.70 \pm 0.59^{\mathrm{a}}$ \\
\hline & MODENA & $178.76 \pm 1.90^{\mathrm{a}}$ & $44.82 \pm 0.62^{\mathrm{b}}$ \\
\hline & LEY & $176.15 \pm 2.04^{\mathrm{a}}$ & $40.59 \pm 0.68^{\mathrm{a}}$ \\
\hline \multirow[t]{3}{*}{24 Hour } & KIEV & $344.37 \pm 4.25^{\mathrm{a}}$ & $92.46 \pm 1.38^{\mathrm{a}}$ \\
\hline & MODENA & $509.05 \pm 1.41^{\mathrm{b}}$ & $101.67 \pm 1.60^{\mathrm{b}}$ \\
\hline & LEY & $343.61 \pm 3.54^{\mathrm{a}}$ & $91.70 \pm 1.36^{\mathrm{a}}$ \\
\hline \multirow[t]{3}{*}{48 Hour } & KIEV & $630.00 \pm 4.86^{\mathrm{a}}$ & $147.61 \pm 1.66^{\mathrm{a}}$ \\
\hline & MODENA & $681.46 \pm 1.87^{\mathrm{b}}$ & $157.56 \pm 2.54^{\mathrm{b}}$ \\
\hline & LEY & $627.43 \pm 3.66^{\mathrm{a}}$ & $143.67 \pm 2.09^{\mathrm{a}}$ \\
\hline \multirow[t]{3}{*}{72 Hour } & KIEV & $757.95 \pm 3.35^{\mathrm{b}}$ & $191.22 \pm 1.73^{\mathrm{a}}$ \\
\hline & MODENA & $822.26 \pm 2.72^{\mathrm{C}}$ & $210.35 \pm 3.52^{\mathrm{b}}$ \\
\hline & LEY & $746.83 \pm 3.82^{\mathrm{a}}$ & $186.46 \pm 2.91^{\mathrm{a}}$ \\
\hline \multirow[t]{3}{*}{96 Hour } & KIEV & $796.21 \pm 3.61^{\mathrm{b}}$ & $206.57 \pm 1.33^{\mathrm{a}}$ \\
\hline & MODENA & $863.90 \pm 2.89^{\mathrm{c}}$ & $227.70 \pm 3.54^{\mathrm{b}}$ \\
\hline & LEY & $784.26 \pm 4.10^{\mathrm{a}}$ & $202.00 \pm 3.04^{\mathrm{a}}$ \\
\hline
\end{tabular}

*Mean value is the average of 54 observations; Mean under same super script in a column did not differ significantly. 
Table 4 Breed wise average enzymatic activity at different hours of preservation (Irrespective of dilutors).

\begin{tabular}{|c|c|c|c|}
\hline Period of preservation & Breed & AST Units $/ 10^{9}$ sperms & ALT Units $/ 10^{9}$ sperms \\
\hline \multirow[t]{3}{*}{0 Hour } & LARGE WHITE YORKSHIRE & $182.58 \pm 1.49^{\mathrm{b}}$ & $45.39 \pm 0.37^{\mathrm{c}}$ \\
\hline & TAMWORTH & $176.57 \pm 1.90^{\mathrm{a}}$ & $41.91 \pm 0.69^{\mathrm{b}}$ \\
\hline & $\mathrm{T} \& \mathrm{D}$ & $174.79 \pm 1.87^{\mathrm{a}}$ & $39.81 \pm 0.67^{\mathrm{a}}$ \\
\hline \multirow[t]{3}{*}{24 Hour } & LARGE WHITE YORKSHIRE & $400.33 \pm 11.29^{\mathrm{a}}$ & $97.20 \pm 1.52^{\mathrm{a}}$ \\
\hline & TAMWORTH & $400.39 \pm 11.05^{\mathrm{a}}$ & $95.26 \pm 1.58^{\mathrm{a}}$ \\
\hline & $\mathrm{T} \& \mathrm{D}$ & $396.30 \pm 11.22^{\mathrm{a}}$ & $93.37 \pm 1.59^{\mathrm{a}}$ \\
\hline \multirow[t]{3}{*}{48 Hour } & LARGE WHITE YORKSHIRE & $645.69 \pm 5.36^{\mathrm{a}}$ & $151.16 \pm 2.29^{\mathrm{a}}$ \\
\hline & TAMWORTH & $647.70 \pm 4.86^{\mathrm{a}}$ & $149.67 \pm 2.29^{\mathrm{a}}$ \\
\hline & $\mathrm{T} \& \mathrm{D}$ & $645.5 \pm 4.81^{\mathrm{a}}$ & $148.00 \pm 2.23^{\mathrm{a}}$ \\
\hline \multirow[t]{3}{*}{72 Hour } & LARGE WHITE YORKSHIRE & $775.52 \pm 5.97^{\mathrm{a}}$ & $195.98 \pm 2.76^{\mathrm{a}}$ \\
\hline & TAMWORTH & $777.13 \pm 5.42^{\mathrm{a}}$ & $199.78 \pm 3.79^{\mathrm{a}}$ \\
\hline & $\mathrm{T} \& \mathrm{D}$ & $774.39 \pm 5.54^{\mathrm{a}}$ & $192.28 \pm 2.71^{\mathrm{a}}$ \\
\hline \multirow[t]{3}{*}{96 Hour } & LARGE WHITE YORKSHIRE & $812.89 \pm 6.33^{\mathrm{a}}$ & $211.57 \pm 2.76^{\mathrm{a}}$ \\
\hline & TAMWORTH & $816.80 \pm 5.79^{\mathrm{a}}$ & $216.04 \pm 3.87^{\mathrm{a}}$ \\
\hline & $\mathrm{T} \& \mathrm{D}$ & $814.7 \pm 5.85^{\mathrm{a}}$ & $208.66 \pm 2.74^{\mathrm{a}}$ \\
\hline
\end{tabular}

* Mean value is the average of 54 observations; Mean under same super script in a column did not differ significantly.

\subsection{Alanine aminotransferase (ALT)}

ALT, an enzyme of transaminase group has significant correlation with percentage of motile spermatozoa, sperm concentration and fertility (Khokhar et al., 1987). Significant effect of dilutors on ALT level was reported by Pandey \& Singh (2001). The assay of enzyme has been widely used to detect sperm cell damage and found to be more sensitive indicator for assessing membrane damage in boar sperm than ultrastructural investigation. Mean value of ALT in preserved semen with three dilutors and three breeds at 24, 48, 72 and 96 hours of preservation were presented in Table 3 and 4 . Perusal of Table - 3 revealed that dilutors used during this study had significant effect on ALT activity at all hours of preservation. This was lowest in Lactose Egg Yolk followed by Kiev and Modena dilutors. Irrespective of dilutors, non-significant effect of breed was observed at all hours of preservation on extracellular activity of ALT.

\section{Conflict of interest}

Authors would hereby like to declare that there is no conflict of interests that could possibly arise.

\section{References}

Azawi OI, Znad MM and Al-Jarrah LH (1990) The correlation between the viability of bovine spermatozoa preserved at ambient temperature and the activity of transaminases. Animal Reproduction Science 22 : 319-323.

Brown KI, Crabo BG, Graham EF, Pace MM (1971) Some factors affecting loss of intracellular enzymes from spermatozoa. Cryobiology 8: 220-224.

Journal of Experimental Biology and Agricultural Sciences http://www.jebas.org
Bower RE Jr, Crabo BG, Pale MM, Graham EF (1973) Effect of dilution and glycerol on the release of GOT from boar spermatozoa. Journal of Animal Science 36 : 319-324.

Ciereszko A, Glogowski J, Strzezek J, Demianowicz W (1992) Low stability of aspartate aminotransferase activity in boar semen. Theriogenology $37: 1269-1281$.

Forejtek P, Navratil S (1984) Relation between aspartate aminotransferase (AST) activity in the seminal fluid and indicators of boar ejaculate quality. Veterinary Medicine 29 : 217-222.

Johnson LA, Aalbers JG, Willems CMT, Sybesma W (1981) Use of boar spermatozoa for artificial insemination. I. Fertilizing capacity of fresh and frozen boar semen in sows on 36 farms. Journal of Animal Science 52: 1130.

Khokhar BS, Singh M, Chaudhary KC (1987) Transaminases in cattle and buffalo (Bubalus bubalis) semen in relation to fertility and seminal characteristics during moderate and colder seasons. Animal Reproduction Science 13: 177- 182.

Khomyak II (1984) The formation of ammonia during incubation and storage of boar semen. Referativnyi Zhurnal, Pig News and Information, 5: 822.

Mann T, Mann CL (1981) Male reproductive function and semen. Springer-Verlag, Berlin, Heidelberg, New York.

Pandey RP (1993) Studies on liquid preservation and potential fertility of boar semen. Ph.D. Thesis submitted to Birsa Agricultural University, Ranchi, Jharkhand.

Pandey RP, Singh BK (2001) Effect of dilutors on extracellular enzyme activity of preserved boar semen. Indian Journal of Animal Sciences $71: 826-828$. 
Park CS, Pursel VG (1985) Effect of cooling rate and duration of freezing point plateau on boar sperm frozen in maxi- straws. Proceeding of First International Conference on Deep freezing Boar Semen, Uppsala, 25-27 Aug. PP. 267.

Pangawkar GR, Sharma RD, Sharma R (1988) Phosphatase and transaminase activity in seminal plasma of bull in relation to freezability of semen. Theriogenology $29: 1393-1399$.

Pursel VG, Johnson LA, Gerrits RJ (1970) Distribution of glutamic oxaloacetic transaminase and lactic dehydrogenase activities in boar semen after cold shock and freezing. Cryobiology 7 : 141-144.

Rasbech NO (1969) A review of the causes of reproductive failure in bovine. British Veterinary Journal 125: 599-616.
Kanshi and Kumar

Reitman S, Frankel S (1957) A colorimetric method for the determination of serum glutamic oxaloacetic and glutamic pyruvic transaminase. American Journal of Clinical Pathology $28: 56-63$.

Skjervold H (1963) To what extent do boars affect the litter size? Meldinger Fra Norges Landbrukshaiskole, Pig News and Information $8: 4$.

Sone M, Chikyu M, Yoshida, M, Kamba K, Ogasa A (1992) Prolonged storage if boar semen in liquid form. Nihon Yoton $\begin{array}{llll}\text { Gakkaishi } & 29 & \text { : } & 41-50 .\end{array}$ http://doi.org/10.5938/youton.29.41.

Zavos PM, Liptrap DO (1987) Procedures for collection, evaluation, dilution and artificial insemination of boar spermatozoa. Argil-Practice $\neg-$ Swine Reproduction 8 : 268 . 